\title{
Distribution, ecology, and conservation of Xenarthra in Bolivia - update to 2021
}

\author{
Enzo Aliaga-Rossel ${ }^{\mathrm{A}, \mathrm{B}, 1}$, Carmen Julia Quiroga ${ }^{\mathrm{C}, \mathrm{D}}$, Ximena Velez-Liendo ${ }^{\mathrm{E}, \mathrm{F}}$, \\ Alfredo Romero-Muñoz ${ }^{\mathrm{G}}$, Zulia Porcel ${ }^{\mathrm{H}}$, Robert Benedict Wallace ${ }^{\mathrm{H}}$, \\ Guido Marcos Ayala ${ }^{\mathrm{H}}$, María Estela Viscarra ${ }^{\mathrm{H}}$, Erika Cuéllar Soto ${ }^{\mathrm{I}}$, \\ TERESA TARIFA \& ANDREW NOSS ${ }^{\mathrm{K}, 1}$
}

\footnotetext{
A Instituto de Ecología, Universidad Mayor de San Andrés, Cota Cota Calle 27, Campus Universitario, La Paz, Bolivia

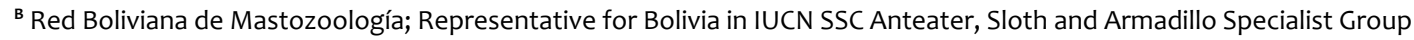

'Museo de Historia Natural «Alcide d'Orbigny», Av. Potosí 1458, Cochabamba, Bolivia

D University of South-Eastern Norway, Gullbringvegen 36, Bo i Telemark, 3800 Norway

E WildCRU, The Recanati-Kaplan Centre, Tubney House, Oxford OX13 5QL, United Kingdom

F Chester Zoo, Cedar House, Upton Chester $\mathrm{CH}_{2}$ 1LH, United Kingdom

${ }^{\complement}$ Geography Department, Humboldt-University Berlin, 10099 Berlin, Germany

${ }^{H}$ Wildlife Conservation Society (WCS) Bolivia, \#340 Gabino Villanueva, Calacoto, La Paz, Bolivia

' Department of Biology, Sultan Qaboos University, Muscat, Oman

J O. J. Smith Museum of Natural History, The College of Idaho, 2112 Cleveland Blvd., Caldwell, ID 83605, United States

${ }^{\mathrm{K}}$ Department of Geography and Center for Latin American Studies, 470 Grinter Hall, PO Box 115560, University of Florida, Gainesville, FL 32611-5560, United States

1 Corresponding authors.

E-mail: ealiagar@hotmail.com (EAR); anoss@ufl.edu (AN)
}

\begin{abstract}
We present an update on the taxonomy, distribution, ecology, threats, and conservation status of Bolivian Xenarthra (orders Cingulata and Pilosa) based on articles published between 2010 and 2021. The Andean hairy armadillo Chaetophractus nationi has been synonymized with the less threatened C. vellerosus. Cabassous squamicaudis has been revalidated for Bolivia. Dasypus kappleri has been divided into three species; D. beniensis is the species present in Bolivia. Cyclopes didactylus was divided into seven species; C. catellus is the species in Bolivia. Chlamyphorus was divided into two genera; Calyptophractus retusus is the species in Bolivia. Recent camera trap and biodiversity surveys extend records of Xenarthra into the dry forests of the central and southern Andes of Bolivia. No comprehensive population assessment or basic ecological studies were undertaken for any Xenarthra species in the country during the period. However, indirectly, armadillos and anteaters have been included in recent studies using camera traps to evaluate effects of forest management, forest fragmentation, agriculture, and hunting on terrestrial mammals. Deforestation is the major threat to Xenarthra, exacerbated by economic pressures, policy changes, and frequent extensive fires in the past decade. The majority of xenarthrans are affected by hunting for subsistence consumption, meat sales, and/or cultural purposes. Overall, the conservation status of Xenarthra species in Bolivia is thought to be relatively stable, with vast protected areas, indigenous territories, and certified forestry concessions where deforestation and hunting are limited. However, outside of protected areas, threats are increasing. Direct research on Bolivian Xenarthra is needed, especially studies on longterm population trends, habitat preferences, and distribution in less-studied and threatened ecosystems such as the Chiquitano Dry Forest and the Bolivian-Tucumán Forest.
\end{abstract}

Keywords: Anteaters, armadillos, sloths, taxonomy, threats 
Resumen Presentamos una actualización sobre la taxonomía, distribución, ecología, amenazas y estado de conservación de los Xenarthra (órdenes Cingulata and Pilosa) en Bolivia, con base en publicaciones entre 2010 y 2021. El armadillo peludo andino (quirquincho) Chaetophractus nationi ha sido sinonimizado con la especie menos amenazada C. vellerosus. Cabassous squamicaudis ha sido revalidado para Bolivia. Dasypus kappleri fue dividido en tres especies; D. beniensis es la especie en Bolivia. Cyclopes didactylus fue dividido en siete especies; C. catellus es la especie en Bolivia. Chlamyphorus fue dividido en dos géneros; Calyptophractus retusus es la especie en Bolivia. Estudios recientes con cámaras trampa y evaluaciones de biodiversidad han extendido la distribución de los Xenarthra a los bosques secos de los Andes centrales y meridionales de Bolivia. No existen evaluaciones poblacionales o estudios ecológicos para ninguna especie de Xenarthra. Indirectamente, los armadillos y osos hormigueros han sido incluidos en recientes estudios con cámaras trampa que evaluaron los efectos del manejo forestal, la fragmentación forestal, la agricultura y la caza de los mamíferos terrestres. La deforestación es la mayor amenaza para las especies de Xenarthra, agravada por la presión económica, los cambios de políticas y los extensos y frecuentes incendios de la última década. La mayoría de las especies están afectadas por la cacería de subsistencia, venta de carne y/o fines culturales. En general, se piensa que el estado de conservación de los Xenarthra en Bolivia es relativamente estable, debido a las vastas áreas protegidas, territorios indígenas y concesiones forestales certificadas donde la deforestación y la caza son aún limitadas. Fuera de las áreas protegidas las amenazas aumentan. Se requiere investigación dirigida hacia los Xenarthra, especialmente evaluaciones de sus tendencias poblacionales, preferencia de hábitat y distribución en ecosistemas menos estudiados y amenazados como los bosques de la Chiquitania y el bosque Boliviano-Tucumano.

Palabras clave: Amenazas, armadillos, osos hormigueros, perezosos, taxonomía

\section{INTRODUCTION}

In Bolivia, the supraorder Xenarthra is one of the least-studied mammal groups. This group consists of two orders, Pilosa and Cingulata, with 16 species recognized in Bolivia: eleven armadillos, two sloths, and three anteaters (Aguirre et al., 2019; Feijó \& Anacleto, 2021; TABLE 1). Noss et al. (2010a, $2010 b)$ published an exhaustive review of the distribution, ecology, and conservation of xenarthrans. Here, we present an update of the research on Xenarthra in Bolivia with focus on their taxonomy, distribution, ecology, threats, and conservation status. We evaluated references published between 2010 and 2021 using the bibliography for armadillos (between 2011 and 2019) on the IUCN SSC Anteater, Sloth \& Armadillo Specialist Group website https://www.xenarthrans.org/armadillo-bibliography/ and all other publications on Bolivian Xenarthra known to the authors.

\section{TAXONOMY}

Although the taxonomy of Cingulata and Pilosa has been stable above the family level, recent analyses using molecular techniques have reorganized the taxonomy of several genera of Bolivian armadillos (Aguirre et al., 2019). The most notable change is the synonymization of the Andean hairy armadillo Chaetophractus nationi (locally called a quirquincho) with the more common screaming hairy armadillo, Chaetophractus vellerosus, based on morphological and molecular analyses of animals from Oruro Department (Abba et al., 2015). Further molecular analyses suggested that C. nationi is a disjunct series of populations of C. vellerosus (Poljak et al., 2018). However, we question the synonymization of $C$. nationi because quirquinchos live exclusively in sand dunes at 4,000 m asl, whereas C. vellerosus are habitat generalists living at lower altitudes, and the two distributions are disjunct.

Analyses for the genus Dasypus by Feijó \& Cordeiro-Estrela (2016) and Feijó et al. (2018, 2019) suggested that the greater long-nosed armadillo D. kappleri was a complex of three species with allopatric distributions, with the Beni greater longnosed armadillo $D$. beniensis being the species that occurs in Bolivia. The genus Cabassous was reviewed by Feijó \& Anacleto (2021), and based on complementary morphological approaches they revalidated the Cerrado naked-tailed armadillo Cabassous squamicaudis which occurs in southern Bolivia. Finally, the genus Chlamyphorus was divided into two genera by Delsuc et al. (2012) and Smith \& Owen (2017), with the genus Calyptophractus replacing Chlamyphorus for the Chacoan fairy armadillo Calyptophractus retusus.

TABLE 1 presents an updated list of the armadillos of Bolivia, with eleven species in six of the eight recognized genera. Only the genera Chlamyphorus and Zaedyus have not been recorded for Bolivia (Aguirre et al., 2019).

In Bolivia, the Order Pilosa includes three species of anteaters: two representatives of the family Myrmecophagidae (the giant anteater Myrmecophaga tridactyla and the southern tamandua Tamandua tetradactyla) and one representative of the family Cyclopedidae (the Amboro silky anteater Cyclopes 
TABLE 1. Current recognized species of Xenarthra in Bolivia following Aguirre et al. (2019) with the exception of Cabassous squamicaudis following Feijó \& Anacleto (2021). Levels of threat follow the IUCN categorization (EN = Endangered; LC = Least Concern; NT = Near Threatened; VU = Vulnerable; DD = Data Deficient), and the Red List for Bolivia (MMAyA, 2009). Cabassous squamicaudis has not yet been evaluated for level of threat.

\begin{tabular}{|c|c|c|c|c|}
\hline Family-subfamily & Species recognized in Bolivia & Synonym & IUCN & Bolivia Red List \\
\hline \multirow{3}{*}{$\begin{array}{l}\text { Dasypodidae / } \\
\text { Dasypodinae }\end{array}$} & Dasypus beniensis & Dasypus kappleri beniensis & $\mathrm{LC}$ & NT \\
\hline & Dasypus novemcinctus & Dasypus novemcinctus novemcinctus & LC & $\mathrm{LC}$ \\
\hline & Dasypus septemcinctus & & $\mathrm{LC}$ & LC \\
\hline \multirow{3}{*}{$\begin{array}{l}\text { Chlamyphoridae / } \\
\text { Euphractinae }\end{array}$} & Chaetophractus vellerosus & $\begin{array}{l}\text { Including former } \\
\text { Chaetophractus nationi }\end{array}$ & $\mathrm{LC}$ & $\begin{array}{l}\text { C. vellerosus and C. nationi } \\
\text { are included in the Bolivia } \\
\text { Red List as NT and EN, } \\
\text { respectively }\end{array}$ \\
\hline & Chaetophractus villosus & & $\mathrm{LC}$ & NT \\
\hline & Euphractus sexcinctus & Euphractus sexcinctus boliviae & LC & LC \\
\hline \multirow{4}{*}{$\begin{array}{l}\text { Chlamyphoridae / } \\
\text { Tolypeutinae }\end{array}$} & Cabassous unicinctus & Cabassous unicinctus unicinctus & LC & $\mathrm{DD}$ \\
\hline & Cabassous squamicaudis & Cabassous unicinctus squamicaudis & - & - \\
\hline & Priodontes maximus & & VU & VU \\
\hline & Tolypeutes matacus & & NT & VU \\
\hline Cyclopedidae & Cyclopes catellus & Cyclopes didactylus catellus & LC & $\mathrm{DD}$ \\
\hline \multirow{2}{*}{ Myrmecophagidae } & Myrmecophaga tridactyla & & VU & NT \\
\hline & Tamandua tetradactyla & & LC & LC \\
\hline $\begin{array}{l}\text { Megalonychidae / } \\
\text { Choloepinae }\end{array}$ & Choloepus hoffmanni & & LC & $\mathrm{DD}$ \\
\hline Bradypodidae & Bradypus variegatus & & $\mathrm{LC}$ & LC \\
\hline
\end{tabular}

catellus; TABLE 1). The genera Myrmecophaga and Tamandua were studied using the entire mitochondrial genome, but the authors found no changes affecting the species present in Bolivia (Ruiz-García et al., 2021). The genus Cyclopes was revised by Miranda et al. (2018) using mitochondrial and nuclear DNA, species delimitation analysis, skull morphology, and pelage color and structure. They divided C. didactylus into seven species, with $C$. catellus being the species in Bolivia (TABLE 1).

Finally, there have been no changes in the number of sloth species present in Bolivia (TABLE 1). Two species of sloths continue to be recognized, including one representative of Megalonychidae (Hoffmann's two-toed sloth Choloepus hoffmanni) and one representative of Bradypodidae (the brown-throated three-toed sloth Bradypus variegatus) (Aguirre et al., 2019). However, a recent mitochondrial DNA study proposed that the morphological subspecies
B. variegatus boliviensis is invalid and Bolivian specimens belong to B. variegatus infuscatus (Ruiz-García et al., 2020).

\section{DISTRIBUTION}

The most recent evaluation of Bolivian medium and large-sized mammals (Wallace et al., 2010) and associated database (Wallace et al., 2013) updated the distribution records of Xenarthra in Bolivia. Here we combine those records with new records collected since 2012 (ANNEX 1, 2; TABLE 2). All distribution maps show records with high (direct observation, specimen collected, high-quality photographs) and medium taxonomic confidence (footprints, tracks, low quality photographs). New distribution records come from four principal sources: camera trap surveys, biodiversity studies, opportunistic visual records by field biologists, and iNaturalist (TABLE 2). Although the iNaturalist 
TABLE 2. New distributional records for Xenarthra species in Bolivia by method (the first three collected by field biologists).

\begin{tabular}{|c|c|c|c|c|}
\hline Species & Camera trap surveys & Biodiversity studies & $\begin{array}{l}\text { Opportunistic visual } \\
\text { records }\end{array}$ & iNaturalist \\
\hline Dasypus beniensis & 44 & 3 & - & - \\
\hline Dasypus novemcinctus & 276 & 14 & 1 & 7 \\
\hline Dasypus septemcinctus & 2 & 2 & 2 & 1 \\
\hline Chaetophractus vellerosus & - & 1 & 2 & 2 \\
\hline Chaetophractus villosus & - & - & - & - \\
\hline Euphractus sexcinctus & 8 & 11 & 1 & 11 \\
\hline Calyptophractus retusus & - & 2 & 1 & - \\
\hline Cabassous spp. & - & - & - & 2 \\
\hline Cabassous unicinctus & - & - & - & - \\
\hline Cabassous squamicaudis & - & - & - & - \\
\hline Priodontes maximus & 122 & 4 & 1 & 3 \\
\hline Tolypeutes matacus & - & 1 & - & 4 \\
\hline Cyclopes catellus & - & 1 & - & 3 \\
\hline Myrmecophaga tridactyla & 167 & 14 & 1 & 10 \\
\hline Tamandua tetradactyla & 51 & 11 & 5 & 11 \\
\hline Choloepus hoffmanni & - & - & 3 & 8 \\
\hline Bradypus variegatus & - & 3 & - & 29 \\
\hline
\end{tabular}

(https://www.inaturalist.org/) citizen science initiative provided abundant data over the last decade, especially at sites near urban areas, we included only records collected by biologists who use that platform, and after validation by the authors of this publication and other specialists. Below we summarize the new records by species.

\section{Dasypus beniensis \\ (Beni greater long-nosed armadillo)}

New records come from the Wildlife Conservation Society's (WCS) long-term camera trap studies in La Paz Department at Pampas del Heath, Madidi National Park and Integrated Management Area, as well as from the Pilón Lajas Biosphere Reserve and Communal Land in Beni Department (WCS, unpublished data). In addition, specimens collected in Beni Department initially reported as D. kappleri were reviewed and validated as D. beniensis by Feijó \& Cordeiro-Estrela (2016).

\section{Dasypus novemcinctus \\ (nine-banded armadillo)}

New records were obtained from WCS's longterm camera trap study in La Paz Department at Pampas del Heath, Madidi National Park and Integrated Management Area, as well as from the Pilón Lajas Biosphere Reserve and Communal Land in Beni Department (WCS, unpublished data). New records also come from sites in Beni Department along the Yacuma River (WCS, unpublished data), in the Great Tectonic Lakes of Exaltación Municipal Protected Area (Montaño, 2016; Ten et al., 2016; G. Ayala \& R. Wallace, pers. obs.), and at Barba Azul Nature Reserve in Yacuma municipality, that is part of the conservation area of the endemic blue-throated macaw (Ara glaucogularis) (Kingsbury, 2010, 2012). A long-term camera-trap study by the Andean Carnivore Conservation Program (PROMETA \& Museo d'Orbigny, Cochabamba) added new records in the dry forests of the central and southern 
Andes of Bolivia at Iñao National Park, Chuquisaca Department and in the San Lorenzo and Cercado provinces of Tarija Department (Velez-Liendo, pers. comm.). iNaturalist records come from Pando Department near Riberalta, Santa Cruz Department near Santa Cruz city, San Miguelito ranch in San Antonio de Lomerío municipality, San Carlos in Amboró Integrated Management Area, and Beni Department near Santa Rosa del Yacuma.

\section{Dasypus septemcinctus ( seven-banded armadillo)}

New records from Pampas del Heath, La Paz Department, as a result of the WCS's long-term camera trap study (Ayala et al., 2021), extend the known range of the species to northwestern Bolivia. Additional camera trap studies in the Llanos de Moxos in Beni Department provided new localities in the Yata basin (UAGRM \& FAUNAGUA, 2017), and in the Great Tectonic Lakes of Exaltación Municipal Protected Area (G. Ayala \& R. Wallace, pers. obs.). Opportunistic records by WCS researchers and others include photographs in grasslands along the Madidi River (La Paz and Beni Departments). An iNaturalist photo reviewed by Anderson Feijó extends this species' range to Pando Department in the extreme north of the country.

\section{Euphractus sexcinctus \\ ( six-banded armadillo)}

New records for Pampas del Heath, La Paz Department, extend the known range of the species to northwestern Bolivia (Ayala et al., 2021). Additional camera trap studies in the Llanos de Moxos in Beni Department reported new localities in the Great Tectonic Lakes of Exaltación Municipal Protected Area (G. Ayala \& R. Wallace, pers. obs.), and at Barba Azul Nature Reserve in Yacuma municipality that is part of the conservation area of the endemic blue-throated macaw (Ara glaucogularis) (Kingsbury, 2010, 2012). More records were added for the dry forests of the central and southern Andes of Bolivia at Iñao National Park, Chuquisaca Department from the long-term camera-trap study by the Andean Carnivore Conservation Program (Museo d'Orbigny, Cochabamba). iNaturalist records come from Vaca Diez, Yacuma and General José Ballivián provinces in Beni Department and from José Miguel de Velasco province in Santa Cruz Department.

\section{Chaetophractus vellerosus (screaming hairy armadillo)}

New records come from field researchers with the Proyecto Quirquincho (Museo d'Orbigny) in Santiago de Huari and Pampa Aullagas municipalities, Oruro Department (Quiroga \& Huayta, 2017); as well as from the boundary of the Kaa Iya National Park and Integrated Management Areas in Santa Cruz Department (Poma-Urey \&
Salazar-Miserendino, 2014). iNaturalist records come from Colcha " $\mathrm{K}$ " municipality in Nor Lípez province and from Uyuni municipality in Antonio Quijarro province, Potosí Department.

\section{Cabassous unicinctus \\ (southern naked-tailed armadillo); Cabassous squamicaudis \\ (Cerrado naked-tailed armadillo)}

These two species have no new records, and their distribution maps are based on Feijó \& Anacleto (2021), who validated the records for both species in Bolivia. The records published by Wallace et al. (2013) are classified as Cabassous spp. because the data are insufficient to confirm species. iNaturalist records include photos of a carapace of Cabassous without the head, from Riberalta in Pando Department, and from San Miguelito ranch, San Antonio de Lomerío municipality, in Santa Cruz Department.

\section{Calyptophractus retusus (greater fairy armadillo)}

Peñaranda Barrios (2020) reported several new records in the Chaco Dry Forest of Tarija Department from biodiversity studies funded by oil companies in their areas of operation.

\section{Tolypeutes matacus \\ (southern three-banded armadillo)}

New camera-trap records come from Cordillera province in Santa Cruz Department (Kosydar et al., 2018). iNaturalist records come from Charagua municipality and from San Miguelito ranch in San Antonio de Lomerío municipality in Santa Cruz Department; as well as from Gran Chaco province in Tarija Department.

\section{Priodontes maximus (giant armadillo)}

New records were reported at sites in Beni Department along the Yacuma River (WCS, unpublished data), and in the Great Tectonic Lakes of Exaltación Municipal Protected Area (Ten et al., 2016; G. Ayala \& R. Wallace, pers. obs.). iNaturalist records come from Abuná Province in Pando Department, Noel Kempff Mercado National Park (San Ignacio municipality), and San Miguelito ranch (San Antonio de Lomerío municipality) in Santa Cruz Department.

\section{Chaetophractus villosus (large hairy armadillo)}

It is noteworthy that the large hairy armadillo has not been recorded in Bolivia in the last 10 years. This may simply be an artefact of the distribution of recent field efforts, because the species was frequently collected by Isoseño hunters in the sand 
dune grasslands of southern Santa Cruz Department in the past (Noss et al., 2008).

\section{Cyclopes catellus \\ (Amboro silky anteater)}

Gutiérrez et al. (2020) reported two visual records of this species in the Piraí River Metropolitan Ecological Park, Santa Cruz Department. This park constitutes an ecotone between the metropolitan area of Santa Cruz de la Sierra and the remaining habitat for wildlife along the Piraí River. The two individuals were observed about $300 \mathrm{~m}$ from human habitation. iNaturalist records come from sites near Cobija in Pando Department, as well as from the municipality of Riberalta in Beni Department.

\section{Myrmecophaga tridactyla (giant anteater)}

There are new records from camera trap studies in the Llanos de Moxos of Beni Department in the Yata basin (UAGRM \& FAUNAGUA, 2017). New records have been reported at sites along the Yacuma River (WCS, unpublished data), within the Great Tectonic Lakes of Exaltación Municipal Protected Area, Beni Department (Montaño, 2016; G. Ayala \& R. Wallace, pers. obs.), and at Barba Azul Nature Reserve in Yacuma municipality that is part of the conservation area of the endemic blue-throated macaw (Ara glaucogularis) (Kingsbury, 2010, 2012). iNaturalist records come from Germán Busch and José Miguel de Velasco provinces in Santa Cruz Department; as well as from Yacuma, San Javier and General José Ballivián provinces in Beni Department.

\section{Tamandua tetradactyla (southern tamandua)}

There are new localities along the Yacuma River in the Llanos de Moxos in Beni Department (WCS, unpublished data), in the Great Tectonic Lakes of Exaltación Municipal Protected Area (Montaño, 2016; G. Ayala \& R. Wallace, pers. obs.), and at Barba Azul Nature Reserve in Yacuma municipality that is part of the conservation area of the endemic blue-throated macaw (Ara glaucogularis) (Kingsbury, 2010, 2012). Additional new records were added at El Palmar National Park, Lagarpampa-Mollepampa Municipal Protected Area, and in the San Lorenzo and Cercado provinces of Tarija Department from the long-term camera-trap study by the Andean Carnivore Conservation Program (Museo d'Orbigny, Cochabamba) (X. Velez-Liendo, pers. comm.). iNaturalist records include the northernmost location for the species, in Nicolás Suárez province, Pando Department; records from Nuflo de Chaves y Cercado, Santa Cruz Department; and others from Cercado and Yacuma provinces, Beni Department.

\section{Choloepus hoffmanni \\ (Hoffmann's two-toed sloth)}

WCS field staff obtained photographic records of one individual at the Santo Domingo community near Apolo, La Paz Department and another individual rescued by Madidi park guards on the Beni River (La Paz/Beni Departments). iNaturalist records come from Nicolás Suárez and Madre de Dios provinces in Pando Department, as well as from Vaca Díez province in Beni Department.

\section{Bradypus variegatus \\ (brown-throated three-toed sloth)}

Camera trap surveys in Yacuma municipality and the Great Tectonic Lakes of Exaltación Municipal Protected Area, Beni Department provided new records (Ten et al., 2016). iNaturalist records come from Vaca Díez, General José Ballivián, Mamoré and Cercado provinces in Beni Department, with many in and near the city of Trinidad; and also from Nuflo de Chaves, Ignacio Warnes, Sara and Andrés Ibañez provinces in Santa Cruz Department.

\section{ECOLOGY}

\section{Habitat selection}

No comprehensive population assessment or basic ecological study has been undertaken for any Xenarthra species in Bolivia in the past decade. However, recent studies have used camera traps to evaluate the effect of forest management activities on terrestrial mammals, including armadillos and anteaters. Arispe Liaños (2018) used camera traps at an Amazonian forest site in northern Santa Cruz Department to evaluate the effects of Forestry Stewardship Council (FSC) certified forest management on terrestrial mammals, including four armadillos (C. unicinctus, D. beniensis, D. novemcinctus, and P. maximus) and two anteaters (M. tridactyla and T. tetradactyla). However, with less than five records per species, comparative analyses could not be conducted for most of the species. For the two species with more than 10 records, $D$. novemcinctus and T. tetradactyla, the author did not detect any significant differences in abundance across forest blocks harvested recently ( $0-1$ year) versus blocks harvested previously (12-14 years).

Kosydar et al. (2014) combined camera traps with track plots at a Chiquitano Dry Forest site (mosaic of protected forest, cattle ranch, and mechanized agriculture) to evaluate the effects of hunting and forest fragmentation on species abundance and richness. Overall, they recorded four armadillo species (D. novemcinctus, E. sexcinctus, T. matacus, and P. maximus) and two anteater species (M. tridactyla and T. tetradactyla). Only D. novemcinctus provided sufficient records for comparative analysis, and the 
differences were not significant between hunted, fragmented, and protected sites. When grouping the records, the four armadillos had reduced abundance in hunted areas, but the two anteaters did not.

Comparing certified timber extraction operations across four countries-Bolivia, French Guiana, Nicaragua, and Guatemala-Polisar et al. (2016) used systematic camera trap survey data to examine the benefits of certification for jaguar conservation specifically and for other species incidentally. They grouped the Xenarthra together, and for the three Chiquitano Dry Forest concessions in Bolivia, they reported xenarthrans to be most abundant at the site with more hunting, fragmentation, and fires. They went further, and proposed D. novemcinctus as a possible candidate for managed hunting by local communities because of the species' high reproductive rate and generalist habitat preferences, although this recommendation is not specific to the Bolivian sites.

Pérez-Zubieta (2011) conducted a field study of highland C. vellerosus (formerly C. nationi) habitat use in the Altiplano of Oruro Department. He monitored track plots and armadillo signs in three types of plots: cultivated potato (Solanum tuberosum) fields, sand dunes, and grasslands. He found more armadillo foraging activity in cultivated fields and in sand dunes as opposed to grasslands, and more armadillo burrows in sand dunes. Real or perceived crop damage fosters negative feelings from local farmers and the author suggested working with them to design and implement appropriate conservation measures.

Quiroga \& Huayta (2017) built single-season occupancy models for C. vellerosus in the municipalities of Huari, Pampa Aullagas, and Orinoca in Oruro Department. In contrast to Pérez-Zubieta (2011), the models suggested that armadillos avoided cultivated areas and preferred a more mixed environment consisting of sand dunes with the presence of Festuca dolichophylla (Poaceae) and Baccharis incarum (Asteraceae). However, the biggest difference between the two studies was that, in the former, the cultivated fields were dominated by quinoa. This difference might suggest an armadillo preference for certain crops, which could potentially affect the level of conflict, either perceived or real, with farmers.

\section{Predation}

Flores-Turdera et al. (2021) completed a study of food habits of jaguar and puma (Puma concolor) in the lower Tuichi and Hondo Rivers in Madidi National Park and Integrated Management Area and Pilón Lajas Biosphere Reserve. They found that Xenarthra were rare prey species: $M$. tridactyla for jaguar; T. tetradactyla and B. variegatus for puma.
A curious predator-prey relationship was noted by Berkunsky et al. (2012) who found two D. novemcinctus and two E. sexcinctus in the nest of a crowned eagle (Urubitinga coronata) in the Moxos savannas of Beni Department. Armadillos have been reported as prey for this eagle elsewhere (Maceda et al., 2003; Pereyra Lobos et al., 2011), and the authors thought that armadillos may be particularly important prey in the breeding season.

\section{Diet}

Wallace \& Painter (2013) reported frugivory by P. maximus in Amazonian forests of Bolivia. The stomach of an individual killed by a subsistence hunter contained exclusively unidentified figs ( $F i$ cus sp.), while at another site they observed feeding signs of the giant armadillo under fig trees.

\section{Behavior}

To better manage a captive population of $C$. vellerosus, de la Quintana et al. (2017) evaluated agonistic behaviors of 12 individuals in the Municipal Zoo Vesty Pakos in La Paz, Bolivia. Agonistic behaviors among males, when several were housed together, included growling, head-butting or body-slamming, and chasing. The most aggressive male did not tolerate any other male, whereas the other males could be habituated to each other and live in pairs. Females were not aggressive to each other.

A spool-and-thread study of T. matacus in the Chaco provided information on daily displacement, burrow and nest use, and feeding behavior (Noss, 2013). The method provided a maximum of five days of tracking, and the $350 \mathrm{~m}$ daily thread was frequently fully drawn out or broken in a single day. Animals slept in nests of dry leaves, dense bromeliads, or burrows of other animals. Observed signs suggested that animals were feeding principally on insects, including termites, and on plants.

\section{THREATS}

\section{Habitat loss}

As elsewhere, deforestation is a major threat to xenarthrans, especially to sloths. Pressures in the lowlands (Amazon forest, Llanos de Moxos savanna, Chiquitano dry forest, Chaco, and Pantanal) are also increasing as a result of economic pressures, policy changes, and frequent fires in the past decade. The modeling work of Romero-Muñoz et al. (2020, see below) found that habitat destruction was the main driver for the shrinkage of high-quality habitat for xenarthrans. International markets for soy and beef have driven the conversion of forests and savannas to farms and ranches, and the construction and improvement of roads (Fehlenberg et al., 2017). Government policy has further 


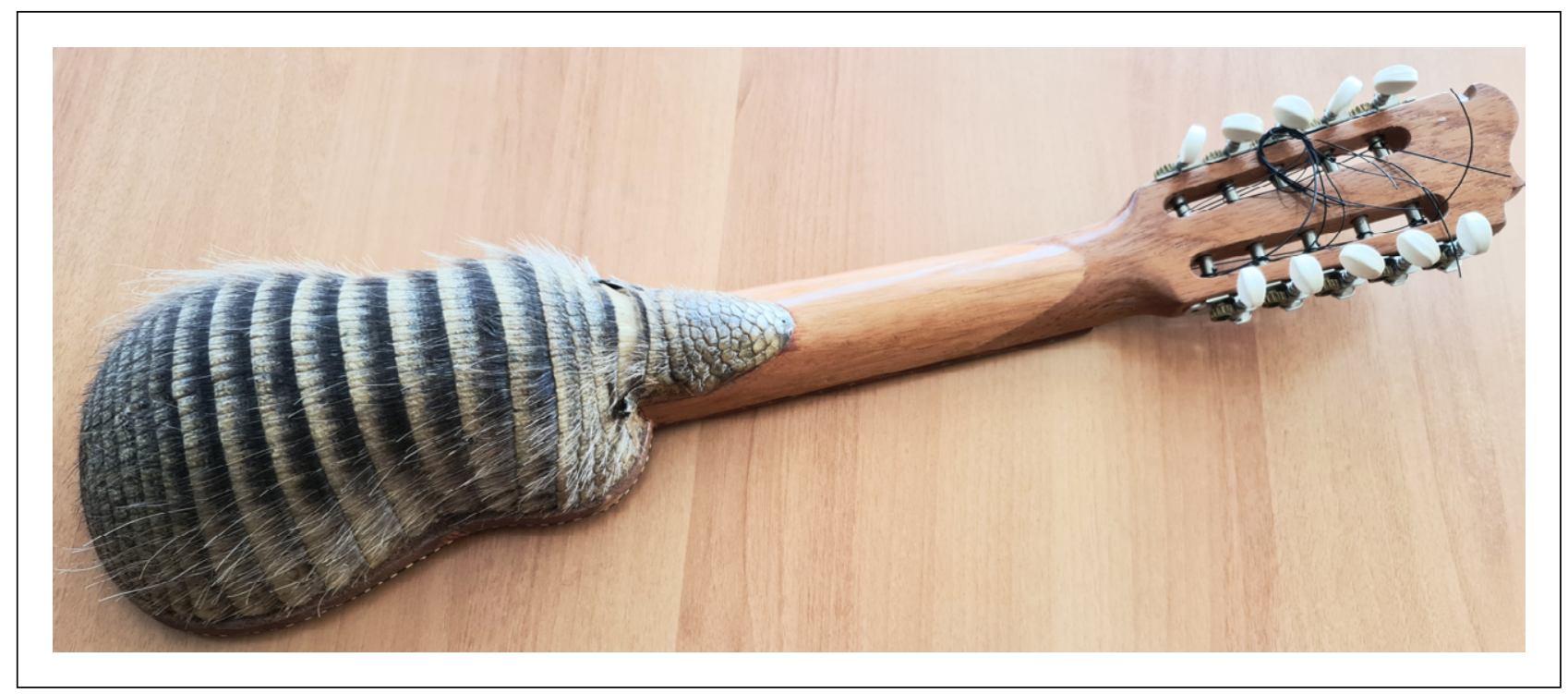

FIGURE 1. Traditional instrument, the charango, using mainly C. vellerosus, formerly C. nationi.

fomented conversion by modifying the ecological zoning from forest land use categories to agriculture. Government policy has also promoted the re-settlement of highland farmers into the lowlands; these colonists clear natural habitats for their settlements and farms (Colque et al., 2019).

Fire is used every year to clear pastures and fields, particularly in savanna formations. However, fires from July to September 2019 were especially severe in Bolivia, with over 5 million ha burned; $74 \%$ of this area was forest as opposed to grasslands. Fires spread into national, departmental, and municipal protected areas, as well as indigenous territories and private lands (Anívarro et al., 2019; NATIVA, 2019a). The severity of the fires was attributed to the coincidence of environmental conditions (drought and winds) with the socio-economic pressures described above (Colque et al., 2019), and the legalization of "controlled burns" in lowland forests (NATIVA, 2019b; Romero-Muñoz et al., 2019). Fires continued to be severe in 2020 and 2021, with unpublished government reports of M. tridactyla, T. tetradactyla, and several species of armadillos burned, and some survivors killed by illegal hunters while escaping the fires (E. Aliaga-Rossel, pers. obs.). Initial analyses of the effects of the fires on wildlife have focused on the jaguar as the umbrella species (Anívarro et al., 2019), but also noted that IUCN Vulnerable species including M. tridactyla and P. maximus were affected (WCS, 2020). News reports also highlighted jaguars, but they did mention anteaters and armadillos among other affected species that were killed or displaced (CE Noticias Financieras, 2019; International Business Times, 2019).

\section{Hunting}

The majority of species of both the Cingulata and Pilosa are affected by hunting. Armadillos, especially Dasypus and Priodontes, are used as a protein source by indigenous and local people throughout their ranges (Noss et al., 2008; Aliaga-Rossel, 2011, ASASG, 2021). Indeed, over the last 30 years, the spatial impact of hunting pressure across the Gran Chaco was as large as that of habitat destruction for xenarthrans (Romero-Muñoz et al., 2020; see below). The law permits subsistence hunting of these species, although some studies show that hunting is not always sustainable (Fragoso et al., 2000; AliagaRossel, 2011), in particular with the acculturation of indigenous people and isolated rural populations. The change from subsistence to commercial armadillo hunting is evident, with armadillos being sold at bus stops in the lowlands along the roads from Cochabamba to Santa Cruz.

In a review of how hunting dogs affect wildlife, Koster \& Noss (2013) re-evaluated hunting records from Isoseño-Guaraní indigenous communities in the Bolivian Chaco. Five armadillo species are commonly hunted for subsistence: $D$. novemcinctus, E. sexcinctus, C. villosus, C. vellerosus, and T. matacus. Dogs were particularly effective at locating the three nocturnal armadillos (D. novemcinctus, C. villosus, T. matacus), and two or more dogs were more effective than a single dog. Although they were not consumed, the anteaters M. tridactyla and T. tetradactyla were occasionally chased and killed by hunting dogs, or killed by the hunters in order to protect the dogs from harm. Researchers here also used local hunters with trained dogs to capture $D$. novemcinctus and T. matacus alive for abundance and health studies (Cuéllar, 2002; Deem et al., 2009). 
Armadillos continue to be hunted for cultural purposes, most importantly quirquincho (C. vellerosus) carapaces for the fabrication of charangos and matracas (Romero-Muñoz \& Pérez-Zubieta, 2008; Fobar, 2019). The charango (FIG. 1) is a small Andean stringed instrument of the lute family, which probably originated by copying guitars during the colonial period. Matracas are rattles used in a traditional dance called the Morenada, performed by hundreds of dancers. Between 2008 and 2009, Porcel (2012) counted over 900 dancers at the Oruro carnival event using matracas made with the carapaces of armadillos. In interviews, many dancers commented that they tend to lose the matracas, break them while dancing, or that they simply have more than one. In a similar study in 2014, Quiroga (2015) counted over 1,500 dancers using matracas.

In order to address this problem, the government made it illegal in 2015 to sell or possess a new matraca (Fobar, 2019). Therefore, in 2016 the Oruro Folklore Groups Association (Asociación de Conjuntos Folklóricos de Oruro or ACFO) declared to the General Biodiversity and Protected Areas Directorate the use of 2,084 matracas (F. Suárez, pers. comm.). Under Administrative Resolution VMABCCGDF No. 004/18 (MMAyA, 15 January 2018) and Inter-Institutional Agreement No. 163 between ACFO, the Ministry of Environment and Water (MMAyA), and the Ministry of Cultures and Tourism, matracas were registered for all dancers in 2019. The agreement seeks to prevent, catalog, regulate, replace, and eliminate the use of wildlife specimens and products in all cultural activities in which ACFO participates. Although the laws forbid and regulate illegal trafficking, the deep-rooted cultural meaning of this species, especially for people living in the High Andes, in addition to a lack of enforcement, make quirquincho hunting a challenge that needs more creative thinking. Quiroga (2015) found that quirquinchos were still widely available in small markets, as they are also used as good luck charms, and to date we do not know whether the demand for these products has decreased or continues. In the lowlands, D. novemcinctus tails are sold as key chains.

\section{Synergistic effects of habitat destruction and hunting}

An expansive modeling study, in both geographic and temporal scales, evaluated the effects of habitat destruction and hunting, acting separately and synergistically, on mammals across the three-nation Gran Chaco region from 1985 to 2015 (Romero-Muñoz et al., 2020). Covering 1.1 million $\mathrm{km}^{2}$, the Gran Chaco became a global hotspot of deforestation due to the expansion of beef and soy agriculture (Hansen et al., 2013). The study combined habitat suitability with hunting-pressure models to map the change in the footprints of both threats, and the consequent change in high-quality habitat over three decades for 48 medium and large-sized mammals with sufficient data to produce reliable habitat models, including eight armadillo and two anteater species. Among sloth species, only B. variegatus reaches the Chaco, but only marginally, and was excluded from the analysis due to insufficient records. On average, xenarthran species lost 3.5\% \pm 25.4 SD of their high-quality habitat between 1985 and

TABLE 3. Percent change in threats affecting Xenarthra in the Gran Chaco region from 1985 to 2015. Major threats were loss of high-quality habitat, hunting pressure, habitat destruction, and the combined effect of hunting pressure and habitat destruction. Source: Romero-Muñoz et al. (2020).

\begin{tabular}{ccccc}
\hline Species & High-quality habitat & Hunting & Habitat destruction & Both threats \\
\hline Dasypus novemcinctus & -17.3 & 5.7 & 118.3 & 110.7 \\
Chaetophractus vellerosus & 40.7 & 39.5 & -27.3 & 3.6 \\
Chaetophractus villosus & 6.4 & 17.2 & 2.9 & 11.0 \\
Euphractus sexcinctus & -1.6 & 0.6 & 10.0 & 23.8 \\
Calyptophractus retusus & 31.6 & 17.9 & 20.9 & 29.7 \\
Priodontes maximus & -55.9 & 43.4 & -10.4 & 47.0 \\
Tolypeutes matacus & -5.1 & 18.1 & 15.3 & 94.8 \\
Myrmecophaga tridactyla & -6.5 & 12.9 & 56.2 & 21.7 \\
Tamandua tetradactyla & -10.8 & 8.2 & 6.6 & \\
\hline
\end{tabular}


2015 (TABLE 3). This value is somewhat misleading because three species-C. vellerosus, $C$. villosus, and Cal. retusus-gained high-quality habitat. However, for the remaining seven species that lost high quality habitat the average loss was $16 \%$. Priodontes maximus lost the most high-quality habitat (55\%), followed by $D$. novemcinctus ( $17 \%$ loss), while M. tridactyla and T. tetradactyla lost $6.5 \%$ and $10.8 \%$ of their habitat, respectively (TABLE 3). On average for all xenarthrans, the footprint of habitat destruction increased by $17 \%$ over this period, that of hunting by $22 \%$, and that of both threats acting together by $42 \%$.

\section{Roadkills}

The construction of new paved roads and the paving of dirt roads, for example the new San Ignacio-Trinidad and San Borja-Yucumo roads in Beni Department, have increased the number of armadillos, sloths, and anteaters killed by vehicles (E. Aliaga-Rossel, pers. obs.). Also, as mentioned previously, animals fleeing forest fires were hit by vehicles. Precise figures for this mortality are not available, but the problem requires further investigation.

\section{Conservation Status}

The recent Supreme Decree 4489 (April 2021) forbids any form of sport hunting in the country, as well as activities related to trade, trafficking, or keeping wild animals as pets. However, the lack of enforcement and public dissemination of the law reduces the effectiveness of this Supreme Decree.

Overall, the conservation status for Xenarthra species in Bolivia is thought to be relatively stable, with vast protected areas (national, departmental, municipal, and private), indigenous territories, and certified forestry concessions where deforestation and hunting are limited. However, some ecoregions are especially threatened. For example, less than $4 \%$ of the inter-Andean Dry Valleys are under some form of protection. Similarly, the vast Llanos de Moxos savannas are poorly represented by national protected areas. Outside of protected areas, the threats are those described above for all species, especially habitat destruction and road kills, as well as hunting of some armadillos for subsistence purposes. It is not currently possible to quantify the increasing number of wildlife killed by fires, traffic, and illegal hunting. In an attempt to model the potential scenarios for the Bolivian Amazon under future land cover change and climate change, Osipova \& Sangermano (2016) used T. tetradactyla, the jaguar, and the lowland tapir (Tapirus terrestris) as a multi-species umbrella, projecting losses of between $70 \%$ and $83 \%$ of their ranges by 2050 .

A positive response to the pressures described above is the creation of new protected areas, most notably Ñembi Guasu (1.2 million ha) and
Guajukaka $(285,000$ ha) by the indigenous municipality of Charagua (Santa Cruz Department). Charagua Iyambae is Bolivia's first legally recognized Autonomous Indigenous Native Campesino municipality, established by the Guaraní indigenous people. The two new protected areas in the Bolivian Chaco connect Otuquis and Kaa-Iya National Parks in Bolivia with Paraguay's Héroes del Chaco Departmental Reserve. These new areas extend legal protection to all the Chaco Xenarthra, with T. tetradactyla, M. tridactyla, and P. maximus cited as vulnerable species that benefit from the new protected areas (Arnold \& Brown, 2018; NATIVA, 2019a,b; Sierra Praeli, 2019a,b). Sadly, to date more than 250,000 hectares of forest in Nembi Guasu were burned and destroyed in the fires described above, affecting all the wildlife present (NATIVA, 2019b).

\section{CONCLUSIONS}

Few researchers in Bolivia are working directly with Xenarthra species, and efforts should be made to encourage the design of field research focused on the new protected areas mentioned above. Records that are by-catch data from studies focused on other species do not provide adequate ecological data to guide effective site-specific conservation measures for Xenarthra in Bolivia. Therefore, specific longterm field studies on habitat preference, distribution, and population trends should be prioritized.

Because C. nationi is no longer recognized as a species endemic to the Bolivian Andes, having been lumped with a more widespread species, it is no longer considered threatened (Vulnerable) by the IUCN. As a result, researchers will face increased difficulties in obtaining funding and generating interest to study this species (Foban, 2019). Officially, the Red List of Vertebrates of Bolivia (MMAyA, 2009) still considers the Andean hairy armadillo (C. nationi) to be endangered, and government legislation focuses specifically on reducing quirquincho exploitation for cultural purposes. The Red List is also over a decade old, and should be updated with systematic evaluations of threats facing each species of Xenarthra today.

Support from government agencies and national and international NGOs to implement protected areas and landscape management activities continue. These efforts, although they benefit Xenarthra in general, focus on emblematic species such as jaguars or threatened habitats, and are not specifically directed to Xenarthra.

New records of Xenarthra were obtained from lesser known or neglected ecosystems such as the Inter-Andean Dry Forests and the Bolivian-Tucumán Forest. The number of threatened ecosystems is increasing, and some are more vulnerable to recurrent forest fires as well as to continuous and frequent 
droughts, such as the High Andean Sand Dunes, Chiquitano Dry Forest, and Bolivian-Tucumán Forest. Further research and conservation efforts should be focused in these ecosystems.

Future research priorities for xenarthrans in Bolivia should include further distribution studies because recent taxonomic changes and known global distributions suggest that at least four additional species could possibly occur in the country. For Cingulata, given nearby records in northern Argentina, it seems probable that the Yungas lesser long-nosed armadillo (Dasypus mazzai) may be present in the extreme south of Bolivia in Tarija Department (Wallace \& Porcel, 2010). Similarly, in the southern portion of the Bolivian Chaco it is very possible that, if Cabassous is present, then the species would be the Chacoan naked-tailed armadillo C. chacoensis, based on Paraguayan records (Wallace \& Porcel, 2010; Smith \& Rios, 2018). For Pilosa, the recent taxonomic revision for Cyclopes (Miranda et al., 2018) is likely to yield additional species for Bolivia. For example, unconfirmed photographic records suggest that the red silky anteater $C$. rufus and Thomas' silky anteater $C$. thomasi may both be present in the north of the country (RAI, 2018).

Finally, the COVID-19 pandemic has changed lives as well as worldwide views on biodiversity, given the possible zoonotic origin of the virus. Preserving biodiversity should be a public health priority. As conservationists, we must increase knowledge and protection of Xenarthra species and their habitats. Our efforts can also benefit from coordination with global initiatives like the UN Decade of Ecosystem Restoration in order to prevent, halt, and reverse the degradation of our ecosystems.

\section{ACKNOWLEDGEMENTS}

We thank all the National Park rangers, in their far-flung and isolated posts, who are committed to protect the biodiversity of the country. We thank Eric Yensen for reading the draft of the manuscript and providing suggestions. We also thank Anderson Feijó for reviewing Dasypus septemcinctus photos. We thank Jim Loughry, Paul Smith, and an anonymous reviewer for their thoughtful revisions.

\section{REFERENCES}

Abba, A.M., et al. 2015. Systematics of hairy armadillos and the taxonomic status of the Andean hairy armadillo (Chaetophractus nationi). Journal of Mammalogy 96: 673-689. https://doi.org/10.1093/jmammal/ gyv082

Aguirre, L.F., et al. 2019. Lista actualizada y comentada de los mamíferos de Bolivia/Updated and annotated check list of mammals from Bolivia. Ecología en Bolivia 54: 107-147.
Aliaga-Rossel, E. 2011. The cascading effect of mammal species defaunation on seed and seedling survivorship as a result of hunting. Doctoral dissertation, University of Hawaii, Manoa. 148 pp.

Anívarro, R., H. Azurduy, O. Maillard, A. Markos \& A. Barrero. 2019. Diagnóstico por teledetección de áreas quemadas en la Chiquitanía. Informe Técnico. Observatorio Bosque Seco Chiquitano, FCBC, Santa Cruz, Bolivia. 70 pp.

Arispe Liaños, M. R. 2018. Efecto en el tiempo del manejo forestal: la respuesta de una comunidad de mamíferos terrestres en un bosque certificado de Bolivia. MSc thesis, Universidad Autónoma Gabriel René Moreno, Santa Cruz, Bolivia. 52 pp.

Arnold, I. \& A. Brown. 2018. Evaluación del Gran Chaco americano. NATIVA, Tarija, Bolivia. 148 pp.

ASASG-Anteater, Sloth \& Armadillo Specialist Group. 2021. Armadillos. https://www.xenarthrans.org/species/armadillos-2/ Accessed on 4 November 2021.

Ayala, G.M., M.E. Viscarra \& R.B. Wallace. 2021. First records of the seven-banded armadillo (Dasypus septemcinctus) and the six-banded armadillo (Euphractus sexcinctus) in northeastern Bolivia. Edentata 22: 42-46. https://doi.org/10.2305/IUCN.CH.2021. Edentata-20-1.6.en

Berkunsky, I., et al. 2012. Records of the crowned eagle (Urubitinga coronata) in Moxos plains of Bolivia and observations about breeding behavior. Revista Brasileira de Ornitologia 20: 447-450.

CE Noticias Financieras. 2019. Species such as jaguar, in the shadow of death. CE Noticias Financieras. 15 September 2019.

Colque, G., E. Tinta, A. Moy, S. Muiba, S. Velasco \& F. Alcons. 2019. Fuego en Santa Cruz: balance de los incendios forestales 2019 y su relación con la tenencia de la tierra. Informe Especial. Fundación Tierra, La Paz, Bolivia. 96 pp.

Cuéllar, E. 2002. Census of the three-banded armadillo Tolypeutes matacus using dogs, southern Chaco, Bolivia. Mammalia 66: 448-451.

de la Quintana, P., G. Ledezma \& L.F. Pacheco. 2017. Evaluación del comportamiento agonista de quirquinchos (Chaetophractus vellerosus) en el Zoológico Municipal Vesty Pakos, La Paz, Bolivia. Edentata 18: 34-41. https://doi.org/10.2305/IUCN.CH.2017. Edentata-18-1.5.en

Deem, S.L., A.J. Noss, C.V. Fiorello, A. L. Manharth, R. G. Robbins \& W.B. Karesh. 2009. Health assessment of free-ranging three-banded (Tolypeutes matacus) and nine-banded (Dasypus novemcinctus) armadillos in the Gran Chaco, Bolivia. Journal of Zoo and Wildlife Medicine 40: 245-256. https://doi. org/10.1638/2007-0120.1

Delsuc, F., M. Superina, M.K. Tilak, E.J. Douzery \& A. Hassanin. 2012. Molecular phylogenetics unveils the ancient evolutionary origins of the enigmatic fairy armadillos. Molecular Phylogenetics and 
Evolution 62: 673-680. https://doi.org/10.1016/j. ympev.2011.11.008

Fehlenberg, V., M. Baumann, N.I. Gasparri, M. Piquer-Rodrigueza, G. Gavier-Pizarrod \& T. Kuemmerle. 2017. The role of soybean production as an underlying driver of deforestation in the South American Chaco. Global Environmental Change 45: 24-34. https:// doi.org/10.1016/j.gloenvcha.2017.05.001

Feijó A. \& T.C. Anacleto. 2021. Taxonomic revision of the genus Cabassous McMurtrie, 1831 (Cingulata: Chlamyphoridae), with revalidation of Cabassous squamicaudis (Lund, 1845). Zootaxa 4974: 47-78. https://doi.org/10.11646/zootaxa.4974.1.2

Feijó A. \& P. Cordeiro-Estrela. 2016. Taxonomic revision of the Dasypus kappleri complex, with revalidations of Dasypus pastasae (Thomas, 1901) and Dasypus beniensis Lönnberg, 1942 (Cingulata, Dasypodidae). Zootaxa 4170: 271-297. https://doi.org/10.11646/ zootaxa.4170.2.3

Feijó, A., B.D. Patterson \& P. Cordeiro-Estrela. 2018. Taxonomic revision of the long-nosed armadillos, Genus Dasypus Linnaeus, 1758 (Mammalia, Cingulata). PLoS One 13: e0195084. https://doi.org/10.1371/ journal.pone.0195084

Feijó, A., et al. 2019. Phylogeny and molecular species delimitation of long-nosed armadillos (Dasypus: Cingulata) supports morphology-based taxonomy. Zoological Journal of the Linnean Society 186: 813825. https://doi.org/10.1093/zoolinnean/zly091

Flores-Turdera, C., G. Ayala, M. Viscarra \& R. Wallace. 2021. Comparison of big cat food habits in the Amazon piedmont forest in two Bolivian protected areas. Therya 12: 75-83. https://doi.org/10.12933/ therya-21-1024

Fobar, R. 2019. Bolivia: armadillos en peligro de extinción utilizados como instrumentos musicales de carnaval. National Geographic LA Newsletter. https://www. nationalgeographicla.com/animales/2019/02/ bolivia-armadillos-en-peligro-de-extincion-utilizados-como-instrumentos-musicales. Accessed on 19 October 2021.

Fragoso, J.M.V., K. M. Silvius \& M. Villa-Lobos, M. 2000. Wildlife management at the Rio das Mortes Xavante Reserve, MT, Brazil: integrating indigenous culture and scientific method for conservation. World Wildlife Fund - Brazil, Brasilia, Brazil. Vol. 4. 68 pp.

Gutiérrez, E.K., D. García, M.A. Pinto-Viveros \& E. Caballero. 2020. Registro de dos ositos de oro (Cyclopes Gray, 1821) en el Cordón Ecológico del Río Piraí, Santa Cruz de la Sierra (Bolivia) y aportes para su conservación. Kempffiana 16: 35-46.

Hansen, M.C., et al. 2013. High-resolution global maps of $21^{\text {st }}$-century forest cover change. Science 342 : 850-853. https://doi.org/10.1126/science.1244693

International Business Times. 2019. More than 2 million animals perish in Bolivia wildfires. International Business Times [U.S. ed.], 26 Sept. 2019, p. NA. Gale Academic OneFile. https://link.gale.com/apps/doc/
A600760912/AONE?u=gain40375\&sid=AONE \& $x-$ $\mathrm{id}=\mathrm{d} 6175008$. Accessed 16 September 2020.

Kingsbury, J. 2010. Bolivia 2010 Expedition report, a joint Glasgow University \& Bolivian expedition to the Beni Savannahs of Bolivia. Informe Técnico. Glasgow University Exploration Society. 110 pp.

Kingsbury, J. 2012. Bolivia 2012 Expedition report, a joint Glasgow University \& Bolivian expedition to the Beni Savannahs of Bolivia. Informe Técnico. Glasgow University Exploration Society. 114 pp.

Koster, J. \& A. Noss. 2013. Hunting dogs and the extraction of wildlife as a resource. Pp. 265-285 in: Free-ranging dogs and wildlife conservation (M.E. Gompper, ed.). Oxford University Press, Oxford. https://doi. org/10.1093/acprof:osobl/9780199663217.003.0011

Kosydar, A.J., D.I. Rumiz, L.L. Conquest \& J.J. Tewksbury. 2014. Effects of hunting and fragmentation on terrestrial mammals in the Chiquitano forests of Bolivia. Tropical Conservation Science 7: 288-307. https://doi.org/10.1177/194008291400700209

Maceda, J.J., J.H. Sarasola \& M.E. María Pessino. 2003. Prey consumed by the Crowned Eagle (Harpyhaliaetus coronatus) in the southern limits of its range in Argentina. Ornitología Neotropical 14: 419-422.

Miranda, F. R., D.M. Casali, F. A. Perini, F.A. Machado \& F.R. Santos. 2018. Taxonomic review of the genus Cyclopes Gray, 1821 (Xenarthra: Pilosa), with the revalidation and description of new species. Zoological Journal of the Linnean Society 183: 687-721. https://doi.org/10.1093/zoolinnean/zlx079

MMAyA - Ministerio de Medio Ambiente y Agua. 2009. Libro Rojo de la fauna silvestre de vertebrados de Bolivia. MMAyA, La Paz, Bolivia. 572 pp.

Montaño, R.R. 2016. Estudio técnico científico para el conocimiento y la consolidación del APM-ANMI Grandes Lagos Tectónicos de Exaltación, provincia Yacuma, departamento del Beni, Bolivia. CIBIOMA \& Universidad Autónoma Gabriel René Moreno, Santa Cruz de la Sierra. 90 pp.

NATIVA. 2019a. El Chajá No 74: Especial Incendios. Revista Informativa sobre Medio Ambiente y el Trabajo de NATIVA. Tarija, Bolivia. 43 pp.

NATIVA. 2019b. El Chajá No 72. Revista Informativa sobre Medio Ambiente y el Trabajo de NATIVA. Tarija, Bolivia. 22 pp.

Noss, A. J. 2013. Seguimiento del corechi (Tolypeutes matacus) por medio de carreteles de hilo en el Chaco boliviano. Edentata 14: 15-22. https://doi.org/10.5537/ 020.014.0103

Noss, A.J., R.L. Cuéllar \& E. Cuéllar. 2008. Exploitation of xenarthrans by the Guaraní-Isoseño indigenous people of the Bolivian Chaco: comparisons with hunting by other indigenous groups in Latin America, and implications for conservation. Pp. 244-254 in: The biology of the Xenarthra (S.F. Vizcaíno and W.J. Loughry, eds.). University of Florida Press, Gainesville. 
Noss, A., E. Cuéllar, H. Gómez, T. Tarifa \& E. AliagaRossel. 2010a. Dasypodidae. Pp. 173-212 in: Distribución, ecología y conservación de los mamíferos medianos y grandes de Bolivia (R. B. Wallace, H. Gómez, Z. R. Porcel \& D. I. Rumiz, eds.). Centro de Ecología Difusión Simón I. Patiño, Santa Cruz, Bolivia.

Noss, A., E. Cuéllar, H. Gómez, T. Tarifa, J. Vargas \& E. Aliaga-Rossel. 2010b. Myrmecophagidae Cyclopedidae - Bradypodidae - Megalonychidae. Pp. 213-234 in: Distribución, ecología y conservación de los mamíferos medianos y grandes de Bolivia (R.B. Wallace, H. Gómez, Z.R. Porcel \& D.I. Rumiz, eds.). Centro de Ecología Difusión Simón I. Patiño, Santa Cruz, Bolivia.

Osipova, L. \& F. Sangermano. 2016. Surrogate species protection in Bolivia under climate and land cover change scenarios. Journal for Nature Conservation 34: 107-117. https://doi.org/10.1016/j.jnc.2016.10. 002

Peñaranda Barrios, E.M. 2020. Nuevos registros del pichiciego mayor, Calyptophractus retusus (Cingulata: Dasypodidae), en el Chaco tarijeño de Bolivia. Acta Zoológica Lilloana 64: 58-64. https://doi.org/10. 30550/j.azl/2020.64.1/5

Pereyra Lobos, R., F.J. Santander, S. Alvarado Orellana, P. A. Ramírez, L. Muñoz \& D. Fernández Bellón. 2011. Diet of the Crowned Eagle (Harpyhaliaetus coronatus) during the breeding season in the Monte Desert, Mendoza, Argentina. Journal of Raptor Research 45: 180-183. https://doi.org/10.3356/JRR-10-36.1

Pérez-Zubieta, J.C. 2011. Intensidad de uso de hábitat del Quirquincho Andino (Chaetophractus nationi) en zonas aledañas a asentamientos humanos de la Provincia Sur Carangas, Oruro, Bolivia. Edentata 12: 28-35. https://doi.org/10.5537/020.012.0105

Polisar, J., et al. 2016. Using certified timber extraction to benefit jaguar and ecosystem conservation. Ambio 46: 588-603. https://doi.org/10.1007/s13280-0160853-y

Poljak, S., A.M. Ferreiro, M.B. Chiappero, J. Sánchez, M. Gabrielli \& M.S. Lizarralde. 2018. Phylogeography of screaming hairy armadillo Chaetophractus vellerosus: successive disjunctions and extinctions due to cyclical climatic changes in southern South America. PLoS One 13: e0190944. https://doi.org/ 10.1371/journal.pone.0190944

Poma-Urey, J.L. \& R.S. Miserendino-Salazar. 2014. Avistamientos de una peji (Euphractus sexcinctus Linnaeus, 1758) llevando su cría. Edentata 15: 66-68. https://doi.org/10.5537/020.015.0110

Porcel, Z.R. 2012. Estimación de la tasa de extracción del quirquincho andino (Chaetophractus nationi) y su red de suministro y comercialización en el Departamento de Oruro. Tesis de Licenciatura, Universidad Mayor de San Andrés, La Paz, Bolivia. 46 pp.

Quiroga, C.J. 2015. Converting cultural value to conservation value: Finding a conservation "niche" for the Andean hairy armadillo. Master's thesis, University of Kent, Canterbury, United Kingdom. 36 pp.
Quiroga, C.J. \& G. Huayta. 2017. Cacería, conflicto o pérdida de hábitat. Qué está causando el declive en la población de Quirquinchos (Chaetophractus nationi). Informe Técnico. Museo de Historia Natural "Alcide d'Orbigny", Cochabamba, Bolivia. 13 pp.

RAI - Red Ambiental de Información. 2018. Descubren dos nuevas especies de osos oro en la Amazonía boliviana. http://www.raibolivia.org/descubren-dosnuevas-especies-de-ositos-oro-en-la-amazonia/. Accessed on 15 October 2021.

Romero-Muñoz, A., et al. 2020. Increasing synergistic effects of habitat destruction and hunting on mammals over three decades in the Gran Chaco. Ecography 43: 954-966. https://doi.org/10.1111/ecog.05053

Romero-Muñoz, A., M. Jansen, A. M. Nuñez, M. Toledo, R. Vides Almonacid \& T. Kuemmerle. 2019. Fires scorching Bolivia's Chiquitano forest. Science 29 Nov 2019: 1082. https://doi.org/10.1126/science.aaz7264

Romero-Muñoz, A. \& J.C. Pérez-Zubieta. 2008. Evaluación preliminar del comercio y uso de mamíferos silvestres en el mercado La Pampa de la ciudad de Cochabamba, Bolivia. Mastozoología Neotropical 15: 253-259.

Ruiz-García, M., D. Chacón, T. Plese \& J. M. Shostell. 2020. Molecular phylogenetics of Bradypus (Three-toed sloth, Pilosa: Bradypodidae, Mammalia) and phylogeography of Bradypus variegatus (Brown-throated three-toed sloth) with mitochondrial gene sequences. Journal of Mammalian Evolution 27: 461-482. https://doi.org/10.1007/s10914-019-09465-w

Ruiz-García, M., D. Pinilla-Beltrán, O.E. Murillo-García, C.M. Pinto, J. Brito \& T.M. Shostell. 2021. Comparative mitogenome phylogeography of two anteater genera (Tamandua and Myrmecophaga, Myrmecophagidae, Xenarthra): Evidence of discrepant evolutionary traits. Zoological Research 42: 525-547. https://doi.org/10.24272/j.issn.2095-8137.2020.365

Sierra Praeli, Y. 2019a. Nembi Guasu: Huge new conservation area in Bolivia's Gran Chaco. https://news. mongabay.com/2019/05/nembi-guasu-huge-newconservation-area-in-bolivias-gran-chaco/. Accessed on 15 September 2020.

Sierra Praeli, Y. 2019b. Bolivia y Paraguay se unen para proteger al guanaco. https://es.mongabay.com/2019/ 06/bolivia-paraguay-proteger-guanaco/. Accessed on 15 September 2020.

Smith, P., \& R.D. Owen. 2017. Calyptophractus retusus (Cingulata: Dasypodidae). Mammalian Species 49: 57-62. https://doi.org/10.1093/mspecies/sex005

Smith, P. \& S. D. Ríos. 2018. Distribution and status of Paraguayan Xenarthra: towards a better understanding. Edentata 19: 1-29. https://doi.org/10.2305/IUCN. CH.2018.Edentata-19-1.2.en

Ten, S., J. A. Díaz-Luque, U. Lombardo \& A. Montejo. 2016 APM Grandes Lagos Tectónicos de Exaltación, un aporte a su conocimiento. Informe Técnico. Consultoría, CIBIOMA - UAB, Beni, Bolivia. 79 pp.

UAGRM - Universidad Autónoma Gabriel René Moreno \& FAUNAGUA. 2017. Levantamiento de biodiversi- 
dad en la región de los Lagos del Rogaguado, sitio Ramsar cuenca Yata, en el complejo de humedales de los Llanos de Moxos-Beni, Bolivia. Informe Final, Proyecto OE 49. 70 pp.

Wallace, R. B. \& R. L.E. Painter. 2013. Observations on the diet of the giant armadillo (Priodontes maximus Kerr, 1792). Edentata 14: 85-86. https://doi. org/10.5537/020.014.0112

Wallace, R.B. \& Z.R. Porcel. 2010. Interrogantes taxonómicas y posibles adiciones para los mamíferos medianos y grandes de Bolivia. Pp. 831-850 in: Distribución, ecología y conservación de los mamíferos medianos y grandes de Bolivia (R.B. Wallace, H. Gómez, Z.R. Porcel \& D.I. Rumiz, eds.). Centro de Ecología Difusión Simón I. Patiño, Santa Cruz de la Sierra, Bolivia. 906 pp.
Wallace, R. B., H. Gómez, Z.R. Porcel \& D.I. Rumiz (eds.). 2010. Distribución, ecología y conservación de los mamíferos medianos y grandes de Bolivia. Centro de Ecología Difusión Simón I. Patiño, Santa Cruz de la Sierra, Bolivia. 906 pp.

Wallace, R.B., H. Lopez-Strauss, N. Mercado \& Z.R. Porcel. 2013. Base de datos sobre la distribución de los mamíferos medianos y grandes de Bolivia. DVD Interactivo. Wildlife Conservation Society, La Paz, Bolivia.

WCS - Wildlife Conservation Society. 2020. Valores de conservación en riesgo por la ocurrencia de focos de calor. Boletín No 1 . WCS - Bolivia, La Paz, Bolivia. $35 \mathrm{pp}$.

Received: 19 October 2021; Accepted: 9 December 2021 


\section{ANNEX 1}

Distribution of the species of armadillos in Bolivia (modified from Wallace et al., 2010, 2013) with new records since 2012. MEDIUM CONFIDENCE: tracks or low-quality photographs; HIGH CONFIDENCE: direct observation, specimen collected, or high-quality photographs. All records since 2012 had a high confidence level.
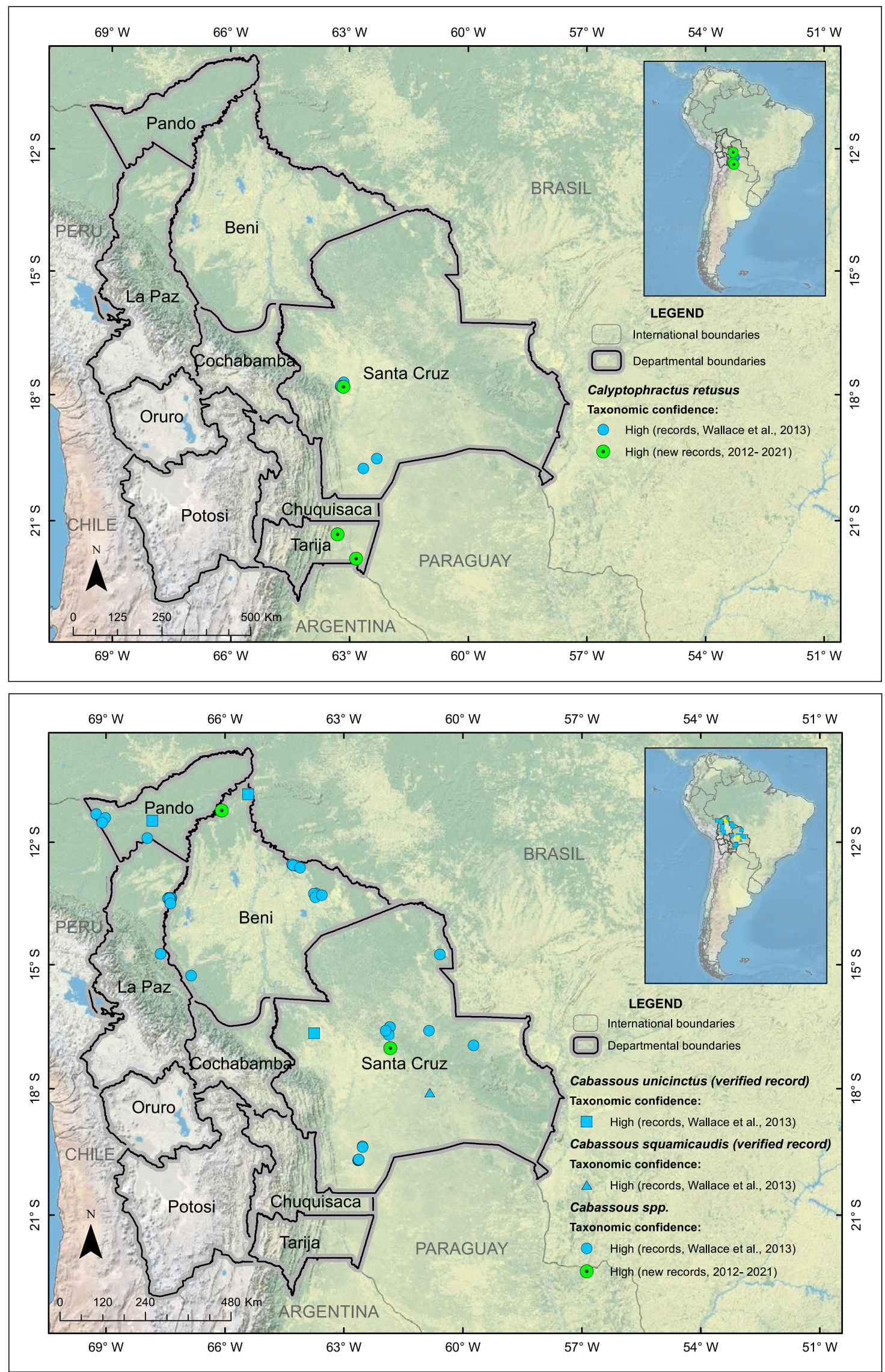

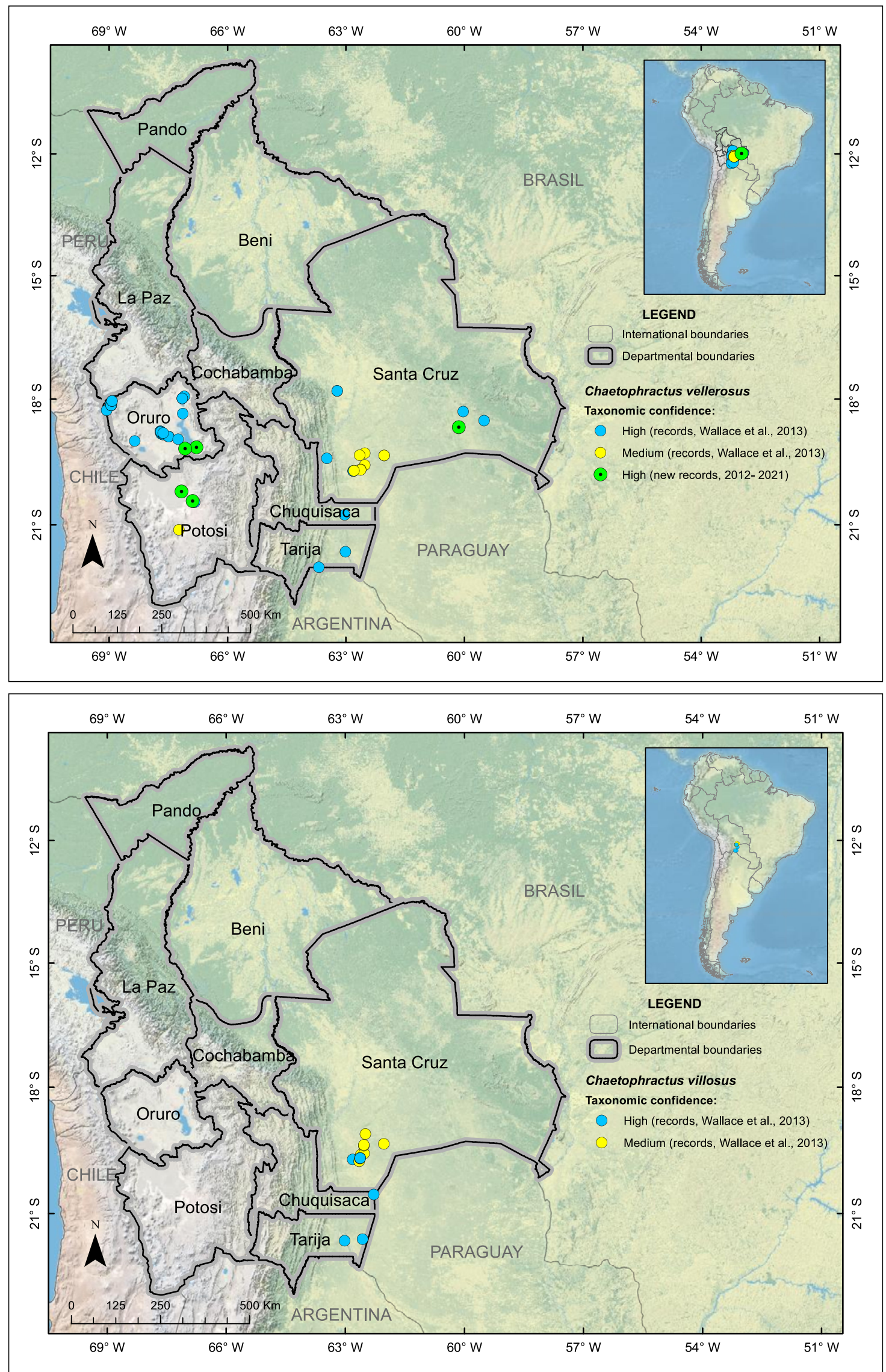

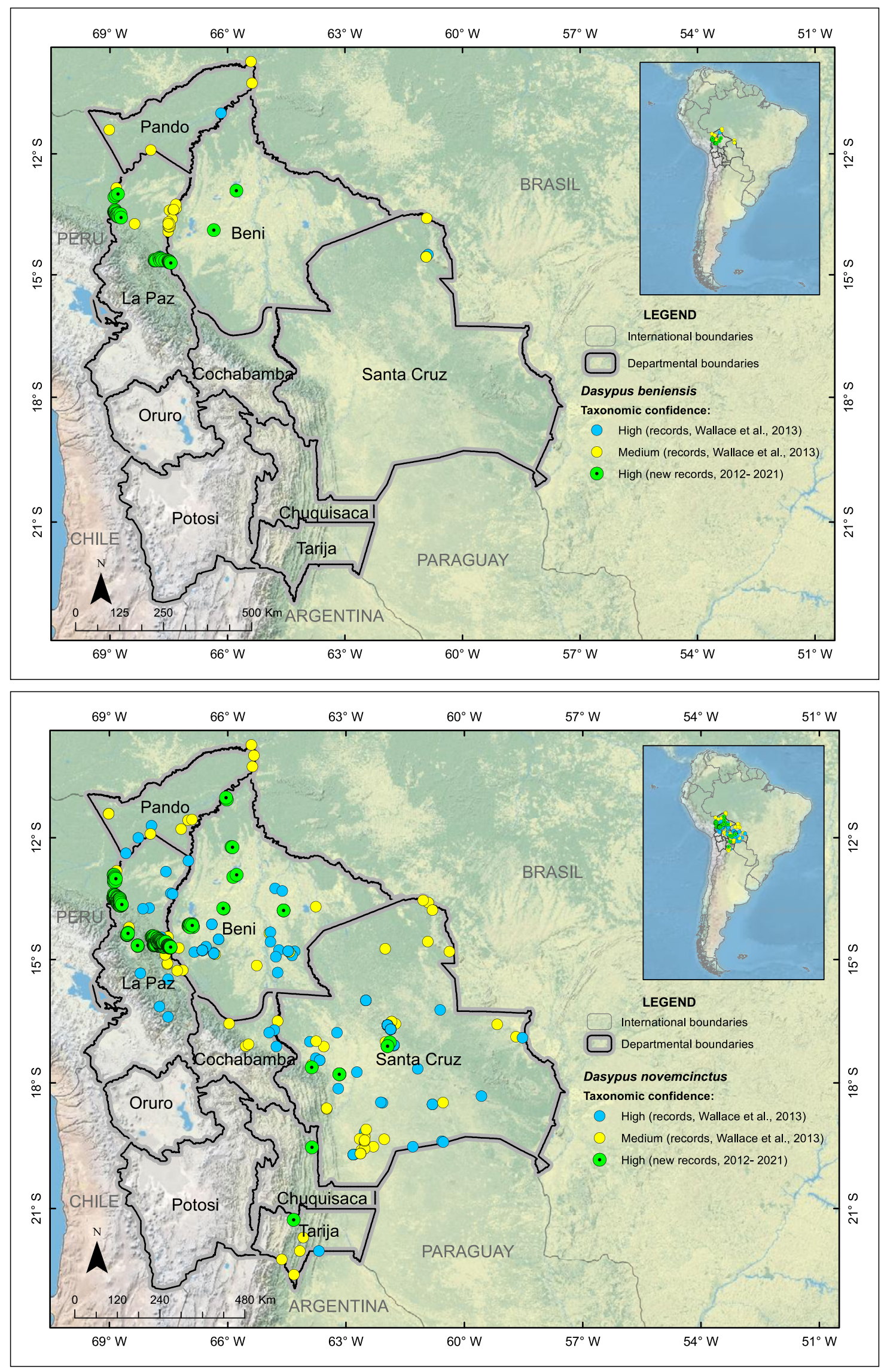

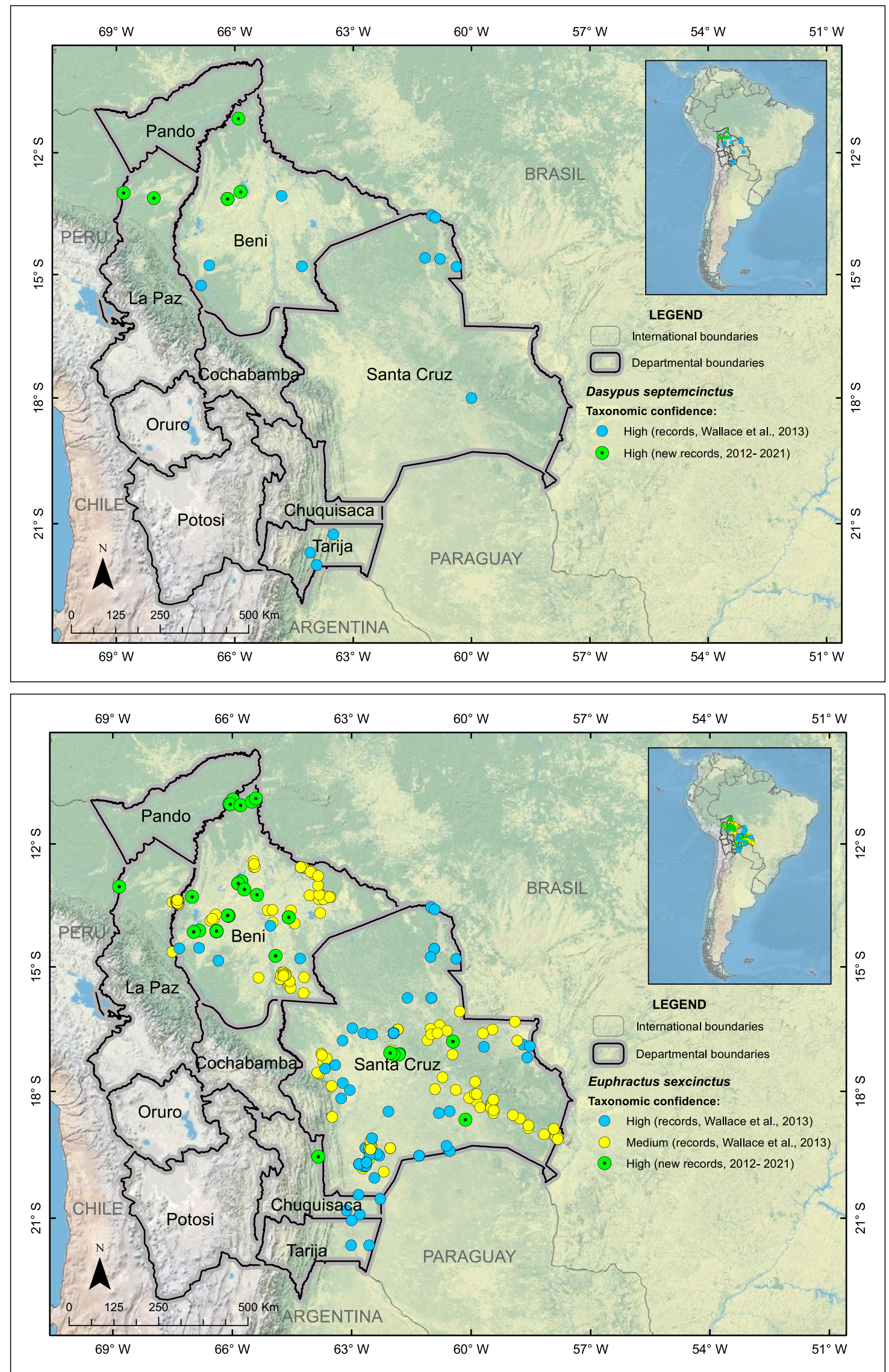

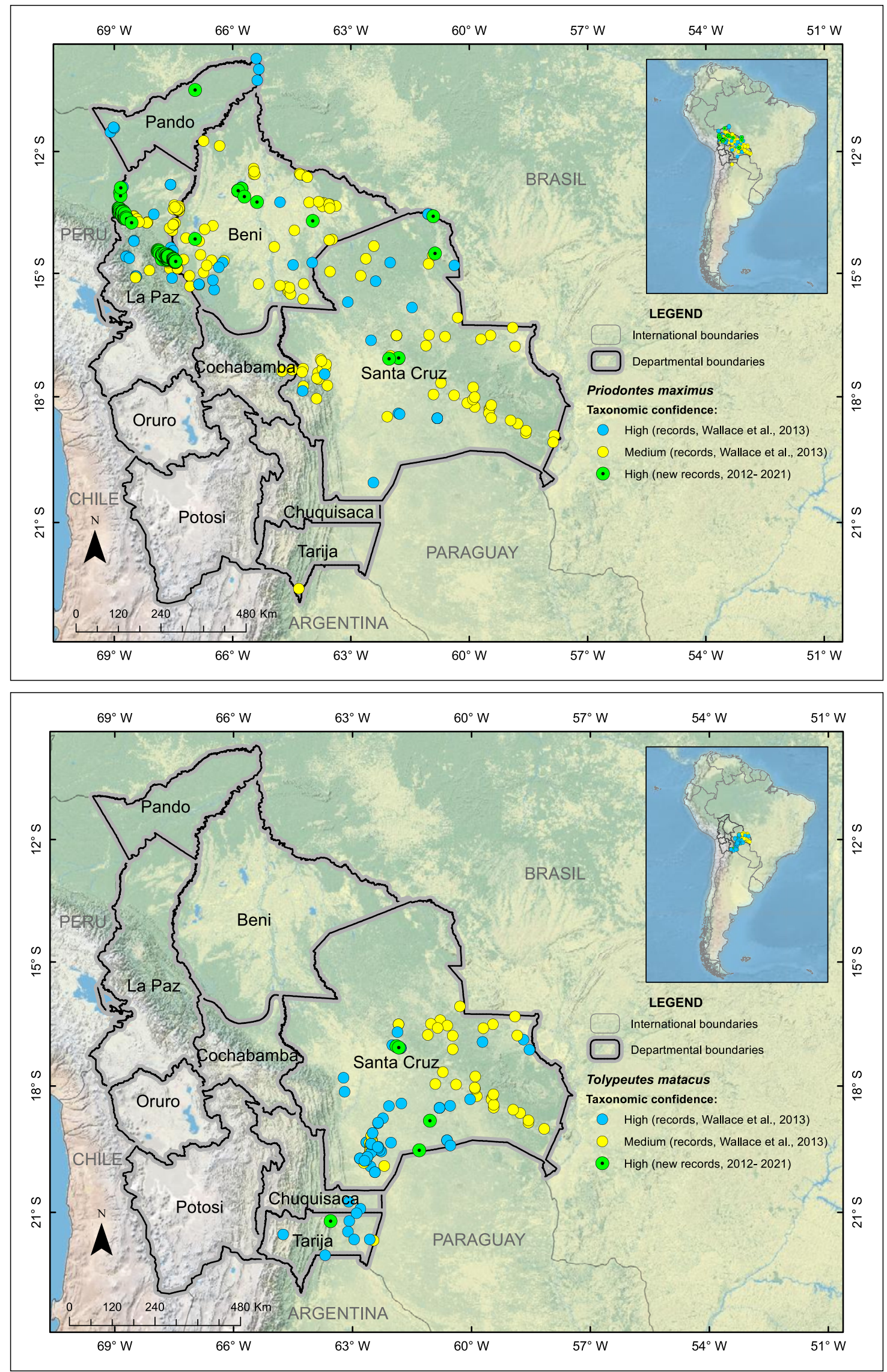


\section{ANNEX 2}

Distribution of the species of Pilosa in Bolivia (modified from Wallace et al., 2010, 2013), with new records since 2012. MEDIUM CONFIDENCE: tracks or low-quality photographs; HIGH CONFIDENCE: direct observation, specimen collected, or high-quality photographs. All records since 2012 had a high confidence level.
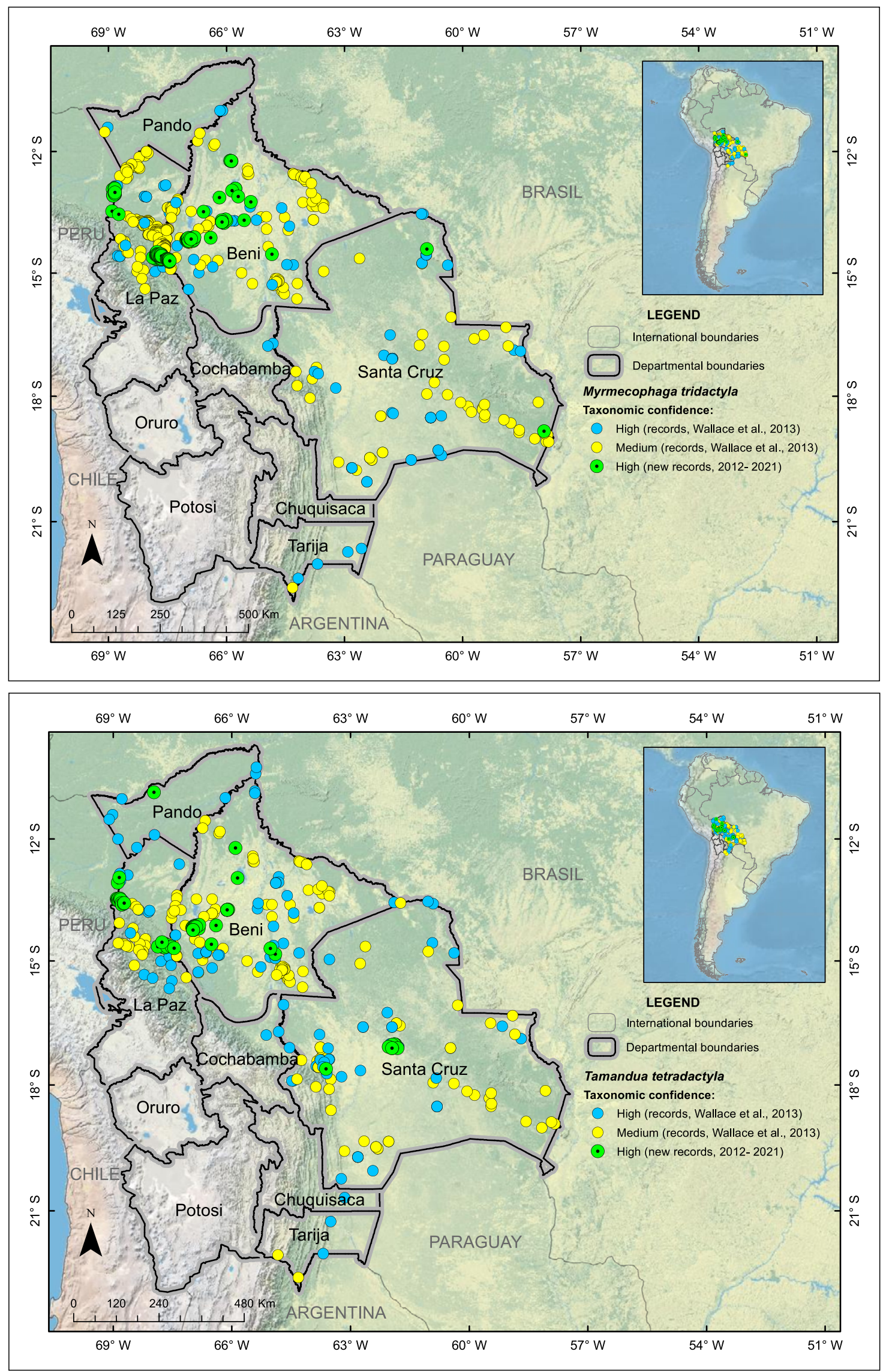

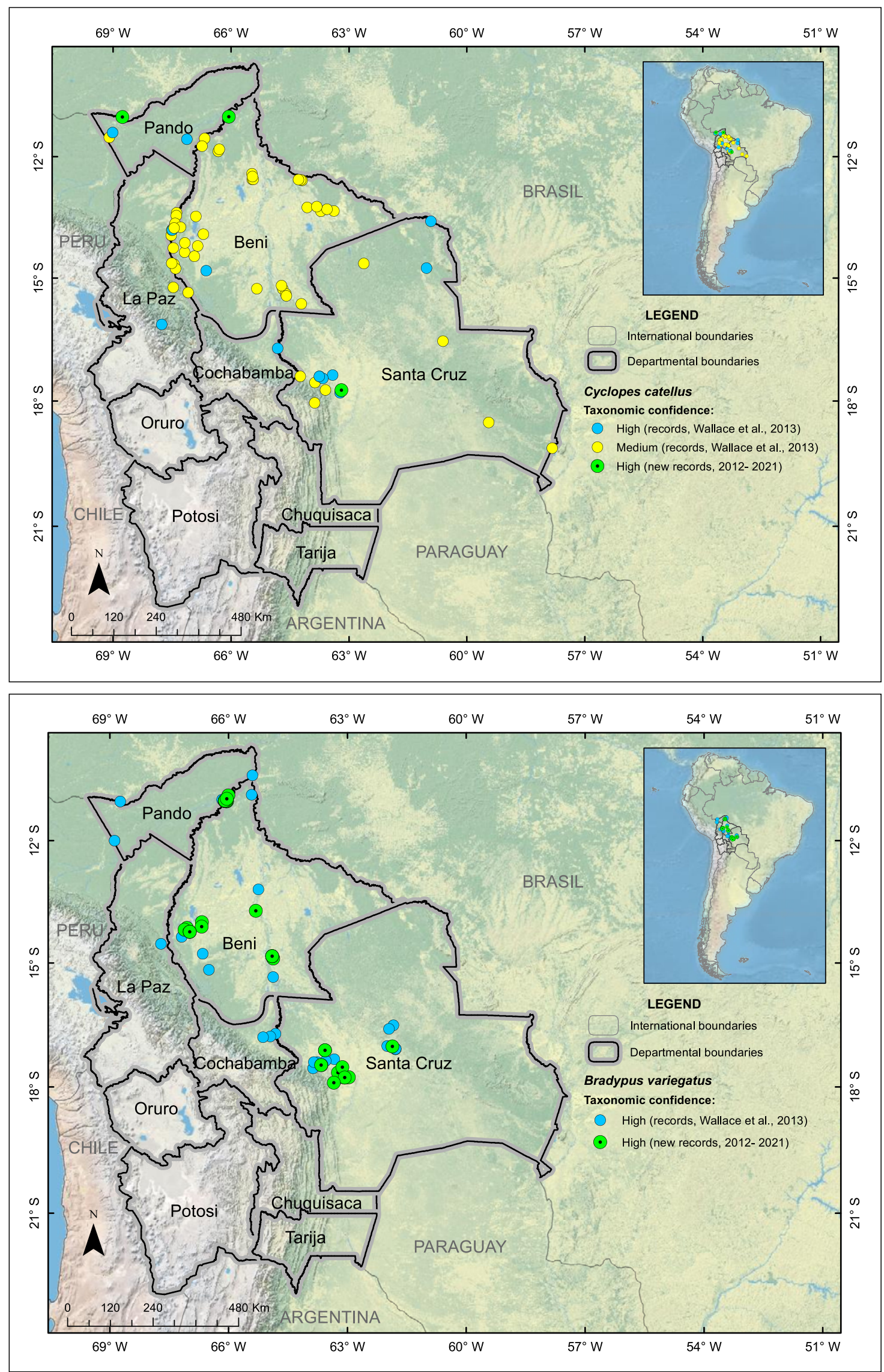


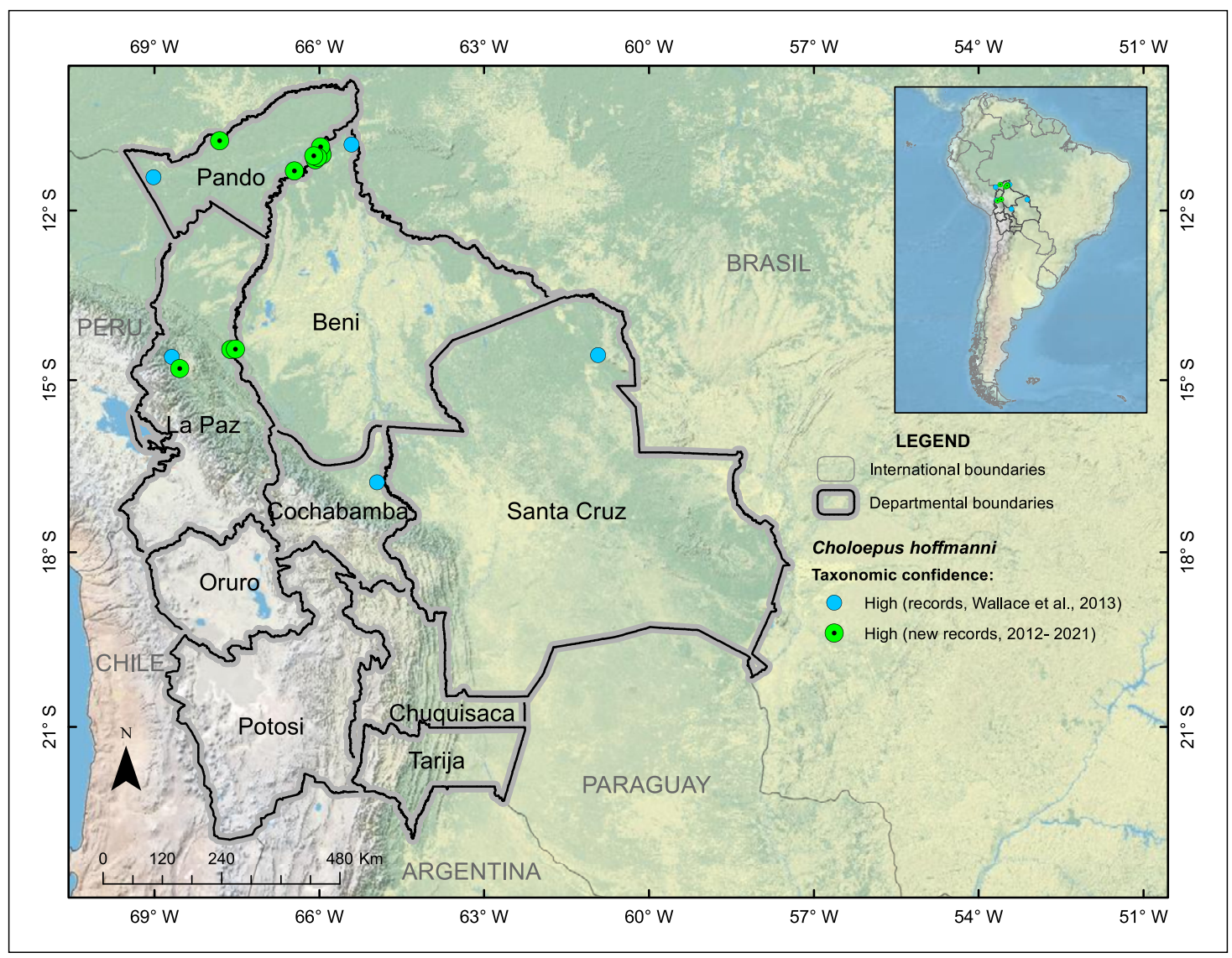

